\title{
Effect of Season and Plant Spacing on Yields of Intensively Managed Soybeans Under Tropical Conditions ${ }^{1,2}$
}

\author{
Servando Silva, José Vicente-Chandler, Fernando Abruña, \\ and José A. Rodriguez ${ }^{3}$
}

\section{INTRODUCTION}

There is little information on the effect of the seasons of the year, and plant spacing, on yields of soybeans in Puerto Rico. Rodriguez ${ }^{4}$ found that soybeans planted in spring, summer, or winter produced very low yields. Gaskins $^{5}$ found that the Hill and Hardee varieties producing 35 and 33 bushels per acre, respectively, outyielded the Clark, Improved Pelican, and F-64-1928 varieties in a June planting. When planted in July, however, these varieties produced only about 15 bushels per acre.

The present study determined the effect of planting date and plant spacing on yields of intensively managed soybeans of the Hardee variety under humid tropical conditions.

\section{MATERIALS AND METHODS}

The experiments were carried out at the Corozal Substation of the Agricultural Experiment Station, College of Agricultural Sciences, Mayaguez Campus, University of Puerto Rico. This Substation is located at an elevation of about 700 feet with temperatures ranging from $64^{\circ} \mathrm{F}$. to $89^{\circ} \mathrm{F}$. The soil is deep, red Corozal clay (Ultisol) with a pH of about 5.0, and an exchange capacity of 18 meq., with 8 meq. of exchangeable bases per 100 grams of soil.

Plantings were made monthly throughout a year with 20-inch $\times$ $31 / 2$-inch, 30-inch $\times 21 / 3$-inch, and 40-inch $\times 13 / 4$-inch spacings $(90,000$ plants per acre).

1 Manuscript submitted to Editorial Board December 6, 1971.

2 This paper reports the results of research conducted cooperatively between the Soil and Water Conservation Research Division, Agricultural Research Service, USDA, and the Agricultural Experiment Station, College of Agricultural Sciences, Mayagüez Campus, University of Puerto Rico, Río Piedras, P.R.

Agricultural Research Technician, Soil Scientist-Project Leader, and Soil Scientist, SWCRD, ARS, USDA, and Research Assistant, Agricultural Experiment Station, College of Agricultural Sciences, Mayagüez Campus, University of Puerto Rico, Río Piedras, P.R.

- Rodriguez, Pastor J., Soybean Trials in Puerto Rico, Agr. Exp. Sta., Univ. P.R. Bull. 75, 1947.

- Annual Report of the Federal Experiment Station at Mayagüez, P.R., 1967. 
An additional planting was made on November 17, 1971 to determine the effect on yields of populations ranging from 80,000 to 650,000 plants per acre, during the winter when plant growth is limited and yields are usually low.

Treatments were replicated four times using 12-foot $\times 12$-foot plots. The soil was limed to $\mathrm{pH} 6.0$ and received 100 pounds of $P$ (as triple superphosphate), 100 pounds of $\mathrm{K}$ (as potassium sulfate), and 50 pounds of $\mathrm{Mg}$ (as magnesium sulfate) per acre in one banded application 2 weeks after planting.

The seed was inoculated, planted in furrows and covered with about 1 inch of soil. Irrigation was applied to supply at least $11 / 2$ inches of water weekly including rainfall. The plots were sprayed weekly with Diazinon and Dithane 45 to control insects and diseases.

The soybeans were harvested and dried to 14 percent moisture. Crude protein, oil content and bean size of selected samples were determined.

\section{RESULTS AND DISCUSSION}

Highest yields were obtained with the closest row spacing combined with widest plant spacing ( 20 inches $\times 31 / 2$ inches) to maintain a population of approximately 90,000 plants per acre (fig. 1).

Soybean yields were markedly affected by season of the year (fig. 1). With a 20-inch $\times 31 / 2$-inch spacing, yields exceeding 40 bushels per acre were obtained in mid-February to mid-September plantings. Highest yields, exceeding 60 bushels per acre, were obtained from May and June plantings and lowest yields, about 20 bushels per acre, from December and January plantings.

Only 70 to 90 days were required to produce a crop with September to January plantings, compared to $\mathbf{1 1 0}$ to $\mathbf{1 3 0}$ days for plantings made during the remainder of the year.

Table 1 shows that yields from a winter crop (planted November 17) were increased from 33.2 bushels with the usual population of about 80,000 plants per acre to 53.1 bushels with 220,000 plants per acre. These high yields were produced during a growing period of only 97 days. It is evident that the smaller plants produced during this season of the year can be planted close together without lodging or markedly reducing yields of the individual plants. A response to even closer spacings may occur with December or January plantings because soybean seeds planted during these months make even smaller plants than seeds planted in November.

Protein content of the soybeans, which ranged from 40 to 44 percent, and oil content, which ranged from 20 to 23 percent, were not affected by spacing or season of the year. Bean size, which ranged from 20 to $24 \mathrm{~g} . / 100$ beans, also was not affected by spacing or season of the year. 


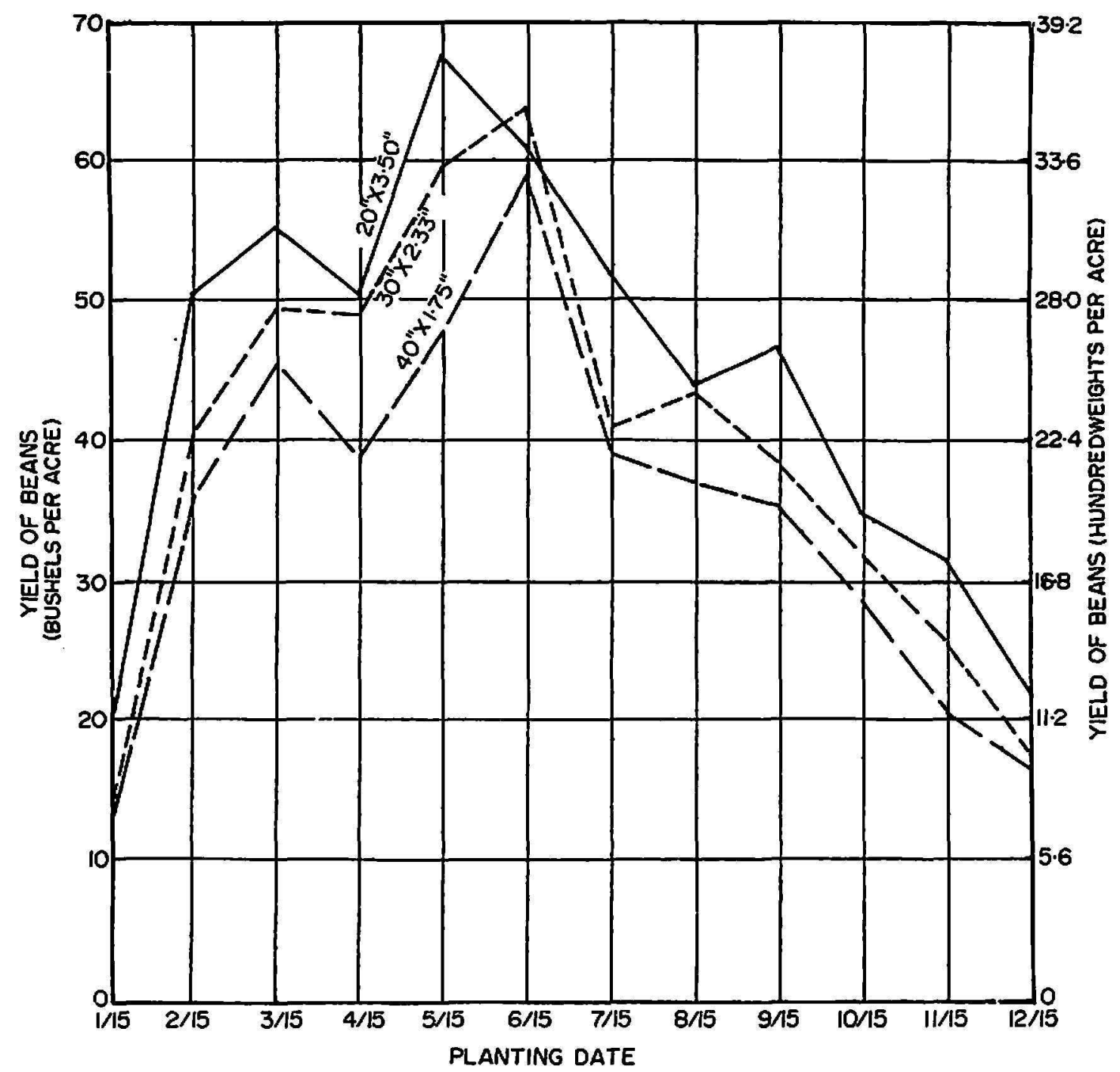

Fig. 1.--Effect of season and spacing on yields of soybeans at Corozal.

T.ıнь: 1.-Effect of plant population on yields of soybeans during the winler of 1971-72 (planlel Nevember 17, harvesled February 24)

\begin{tabular}{crc}
\hline Average spacings & Plants per acre & Yields \\
\hline Inches & & Bushicls/acre \\
$18 \times 4.3$ & 80,000 & 33.2 \\
$6.4 \times 6.4$ & 150,000 & 42.4 \\
$5.2 \times 5.2$ & 220,000 & 53.1 \\
$4.2 \times 4.2$ & 350.000 & 54.6 \\
$3.5 \times 3.5$ & 500,000 & $5 i .8$ \\
$3.1 \times 3.1$ & $(550,000$ & 58.8
\end{tabular}

The data in this patper show that two (rops of soyberans, with eombined yiclds of over 100 bushels (about ti,000 pounds) por acre worth $\$ 300$, caul

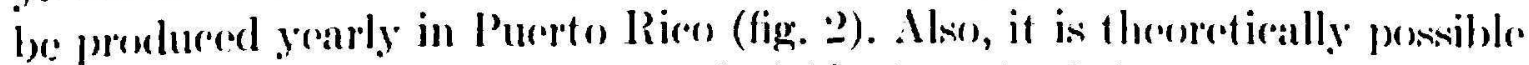

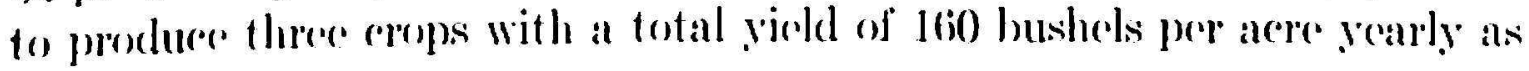




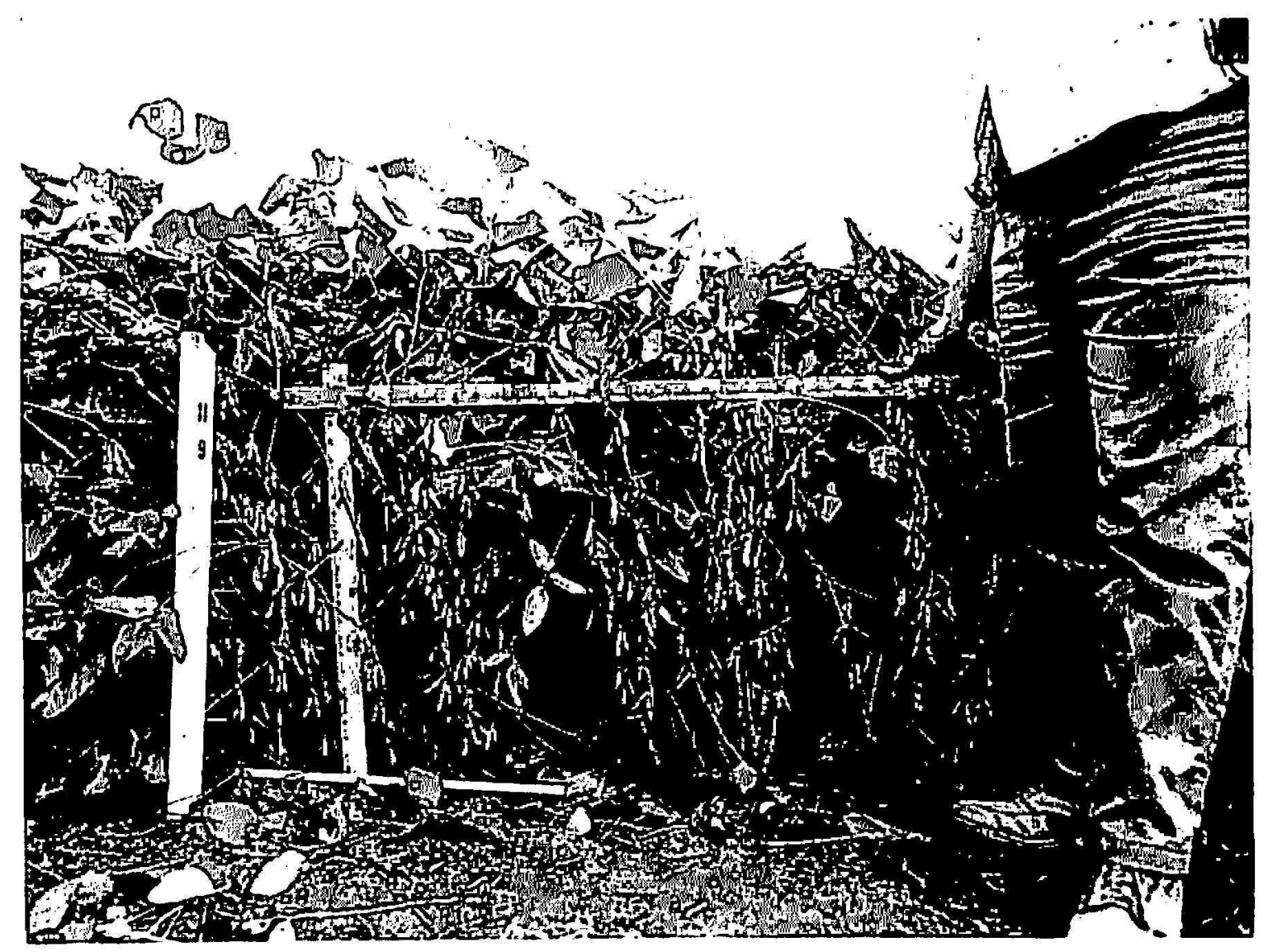

Fig. 2.-Two crops of intensively managed, closely spaced soybeans of the Hardee variety can produce $(;, 000$ pounds of beans (over 100 bushels) per acre yearly containing 2,500 pounds of dry protein and 1,300 pounds of oil.

shown below. Iittlo land preparation is required with most Ultisols or Oxisols.

\begin{tabular}{lcc}
\hline Planting date & Harvested in & Yield \\
\hline Month & Days & Bushels per acre \\
November & 95 & 53 \\
March & 115 & 53 \\
July & 125 & 54 \\
Total & 335 & 160 \\
\hline
\end{tabular}

Onc hundred bushels of soyboans produced in tuo crops yearly, contain ahout 1,300 pounds of oil and 2,500 pounds of good quality dry protein. This cont rasts with about 250 pounds of dry protein per acre yearly which (all be produced by cattlo grazing intensivoly managed pastures in l'uerto

“2:21,,001 plants por acre. 
Rico (Vicente-Chandler, et al.) ${ }^{7}$ However, cattle can be effective protein producers on steep, non-mechanizable lands requiring protection against erosion afforded by grasses.

\section{SUMMARY}

Soybeans of the Hardee variety planted at 20 inches $\times 31 / 2$ inches yielded over 40 bushels per acre when planted from mid-February to mid-September. The highest yields, exceeding 60 bushels per acre, were obtained from May and June plantings and the lowest, about 20 bushels per acre, from December and January plantings with 90,000 plants per acre in all cases. Yields can be increased markedly during the winter by increasing populations to about 200,000 plants per acre.

Higher yields were obtained with 20 -inch $\times 31 / 2$-inch than with 30 . inch $\times 2 \frac{1}{3}$-inch or 40 -inch $\times 13 / 4$-inch spacings.

Bean size and protein and oil contents were unaffected by plant spacing or season of the year.

It is possible to produce two crops of soybeans yearly in Puerto Rico with a combined yield of over 100 bushels (6,000 pounds) per acre containing about 2,500 pounds of dry protein and 1,300 pounds of oil. Three crops with a total yield of 160 bushels per acre yearly are theoretically possible.

\section{RESUMEN}

Habichuelas soyas de la variedad Hardee, sembradas a una distancia de 20 pulgadas $\times 31 \frac{1}{2}$ pulgadas, produjeron más de 2,250 libras por acre cuando se sembraron desde mediados de febrero hasta mediados de septiembre. Las producciones más altas, que excedieron 3,400 libras por acre, se obtuvieron en las siembras de mayo y junio, y las más bajas, unas 1,200 libras por acre, en las de diciembre y enero. Puede aumentarse la producción durante los meses de invierno sembrando unas 200,000 plantas por acre.

Se obtuvieron mayores producciones cuando las habichuelas se sembraron a una distancia de 20 pulgadas $\times 31 / 2$ pulgadas que cuando se sembraron a 30 pulgadas $\times$ $21 / 8$ pulgadas 640 pulgadas $\times 19 / 2$ pulgadas. En todos los casos se sembraron unas 80,000 plantas por acre.

La época del año y la distancia de siembra no afectaron el tamaño de los granos ni su contenido de proteínas y aceite.

En Puerto Rico es posible producir dos cosechas de habichuelas soyas al afio con una producción combinada de unas 6,000 libras por acre, con un contenido de 2,500 libras de proteína y 1,300 de aceite. Es teóricamente posible producir tres cosechas al afio con una producción total de unas 9,000 libras por acre.

7 Vicente-Chandler, J., Caro-Costas, R., Pearson, R. W., Abrufa, F., Figarella, J., and Silva, S., The Intengive Management of Tropical Forages in Puerto Rico, Agr. Exp. Sta., Univ. P.R., Bull. 187, 152 pp., 1964. 